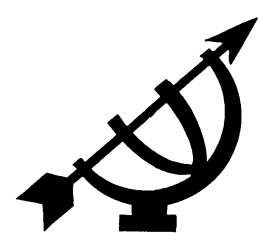

\title{
How to compare cultures? The case of historical thinking
}

\author{
Jörn Rüsen1 \\ School of Basic Sciences \\ Vaal Triangle Campus \\ North-West University \\ VANDERBIJLPARK \\ E-mail: joern.ruesen@kwi-nrw.de
}

\begin{abstract}
How to compare cultures? The case of historical thinking

Comparative studies in historiography are rare. In most cases authors use a pre-given idea of the essentials of historical thinking and historiography to compare Western with nonWestern phenomena in the field of historical representation in general, and historiography in particular. This approach to comparison is very problematic since the presupposed paradigm of historiography is an abstraction in the Western tradition. As a consequence this comparison brings about knowledge on non-Western historical thinking and historiography in so far as it is similar to or different from the Western one. Difference normally imply deviation or a lack of historicity. However, comparing Western historiography with Chinese historiography, does not bring about such a big difference as we witness in the case of for example India. Nevertheless, a cultural bias in the comparative work exists that makes the results of comparative work problematic.
\end{abstract}

The article proposes a theoretical means of intercultural comparison that is grounded in a general theory of historical thinking, presented in the form of its matrix. This matrix is explicated, discussed and differentiated into a set of items which can be used as criteria of comparison.

1 Jörn Rüsen is an extraordinary professor in the School of Basic Sciences, North-West University. He is also president of the Institute for Advanced Study in the Humanities in Essen, Germany. 


\section{Opsomming}

\section{Hoe om kulture te vergelyk? Die kwessie van historiese denke}

Vergelykende studies in historiografie is skaars. In die meeste gevalle gebruik outeurs 'n voorafgegewe idee van wat beskou word as die essensie van historiese denke en historiografie. Daardeur word dan gepoog om Westerse en nie-Westerse verskynsels te vergelyk. Dit is veral die geval op die terrein van historiese representasie in die algemeen en historiografiese denke in die besonder. Hierdie benaderingswyse is problematies. Die vooropgestelde historiografiese paradigma is gewoonlik 'n abstraksie van die Westerse tradisie. Omdat die vooropgestelde paradigma gevolglik 'n abstrahering van die Westerse tradisie verteenwoordig, dra dit by tot kennis van nieWesterse historiese denke en historiografie in soverre dit van die Westerse tradisie verskil. Verskil impliseer gewoonlik 'n afwyking of 'n gebrek aan historisiteit. Die verskil tussen Westerse en Chinese historiografie blyk gering te wees wanneer dit teen die agtergrond van byvoorbeeld die Indiese geskiedenis beskou word. Tog bestaan daar 'n kulturele voorkeur in vergelykende werk. Die resultate van vergelykende werk het gevolglik' $n$ problematiese aard.

In die artikel word 'n teoretiese strategie aan die hand gedoen om interkulturele vergelyking wat gebaseer is op 'n algemene teorie van historiese denke te bewerkstellig. Hierdie strategie word uiteengesit in die vorm van 'n matriks wat verduidelik en bespreek word. Voorstelle word ook gemaak aangaande 'n gedifferensieerde stel kriteria wat vir vergelykingsdoeleindes gebruik kan word.

\section{Introduction: Comparison as a matter of theory}

Most works on historiography are done within the framework of a national history (Blanke, 1991). A broader perspective is related to European or Western historiography (Breisach, 1983; Iggers, 1993; Iggers \& Parker, 1979) or to the historiography of non-Western cultures. The latter mainly deals with a specific country or a specific culture like China (Beasley \& Pulleyblank, 1962; Gardner, 1961; Kao, 1982; Trauzettel 1984) or India (Devahuti, 1979; Asthana, 1992, Gottlob, 1995:123-144). Comparative studies are rare (Brown, 1988; Küttler, Rüsen \& Schulin, 1993a and Rüsen 1993b, 1994, 1996, 1997, 1999). There are a lot of reasons why comparative studies are rarely undertaken: only two of them will be mentioned:

- The difficulty of combining the competencies of research in different historical cultures and 
- the dominance of Western historical thinking in historical studies - even in non-Western countries. This dominance draws academic attention to the origins and development of specificically the contemporary way of historical thinking.

On the other hand a growing need for intercultural comparison exists - simply and unavoidably because of the increasing growth of international and intercultural communication, not only in economics and politics, but also in various fields of cultural life.

\subsection{Intercultural comparison needs an organisational paramenter}

Thus the following question arises: How should such an intercultural comparison be undertaken (cf. Osterhammel, 1996:143-164; Haupt \& Kocka, 1996)? It is not sufficient to combine different histories of historiography. This method may be a useful and even necessary way to get an overview of the hitherto available knowledge, but it is no comparison whatsoever, since the different stocks of knowledge lack a common framework of cognitive organisation. Every comparison needs an organising parameter. Before looking at the materials (texts, oral traditions, images, rituals, monuments, memorials, etcetera), one needs to know what realm of things should be taken into consideration and in what respect the findings in this realm should be compared. To put it more simply: We should ask for corresponding facts and conformities and find out the differences in the field of historiography.

This simple starting point entails a very complex way of answering it. Intercultural comparison of cultural issues is a very sensitive matter - it touches the field of cultural identity, and it is therefore involved in the struggle for power and domination among different countries, especially in respect to Western dominance and non-Western resistance on practically all levels of intercultural relationship. It is, however, not only a political struggle for power that renders the field of historical thinking in intercultural comparison problematic. Beyond politics there is an epistemological difficulty with enormous conceptual and methodological consequences for the humanities: Every comparison is done in the context of a pre-given culture; thus the context is involved in the subject matter of the comparison itself. Looking at historical thinking in other cultures with a historical interest is normally undertaken with a concept of historiography, pregiven by the cultural background of the scholar. As a historian he or she knows what historiography is and therefore has no urgent reason to reflect or explicate it theoretically. This pre-given 
knowledge of what historiography is, functions as a hidden parameter, as a norm, or, at least, as a unit of structuring the outlook on the variety of historical thinking in different places and times.

Non-awareness of what historiography entails offers a problem: In a comparison a single case of historical thinking has an unreflected meta-status, and it is therefore more than only a matter of comparison, it pre-shapes its results: the 'real' or the essentially 'historical' mode of historiography naturally can only be found in this pre-given paradigm, and the other modes get their meaning, significance and importance only in relation to it. ${ }^{2}$ Comparison in this respect is nothing but measuring the proximity or distance from the pre-supposed norm. In most cases this norm is the mode of one's own historical thinking, of course. In other rarer cases the scholar may use projections of alternatives into other cultures in order to criticise his or her own point of view; but even in this case he or she never gets a substantial insight into the peculiarities and the similarities of different modes of historical thinking and historiography.

\subsection{A theory of comparison implies reflection, explication and discussion}

There is no way of avoiding the clashes between involvement and interest concerning the historical identity of the people whose historiography must and should be compared. This involvement and interest have to be systematically taken into consideration. They require reflection, explication and discussion. There is, at least, one way of doing so and this way creates the opportunity to reach comprehensive insights and cognition, and potential agreement and consensus among those who feel committed to, or, at least, related to the different cultures in concern. This way of doing implies theory, i.e. a certain way of reflecting and explicating the concepts and strategies of comparison. Only by theoretically explicit reflection the standards of comparison can be treated in a way that prevents any

2 A typical example is Brown (1988). Rosenthal's (1968:17) views reflect the problem when dealing with the subject matter of 'Muslim historiography': He identifies it as "those works which Muslims, at a given moment of their literary history, considered historical works and which, at the same time, contain a reasonable amount of material which can be classified as historical according to our definition of history...". 
hidden cultural imperialism or misleading perspective or, at least, it may be corrected. ${ }^{3}$

An intercultural comparison pre-supposes cultures as the subject matter of its work. It is an open question how these units of comparison should be looked at. Are there pre-given entities, well distinguished in time and space? If an intercultural comparison uses a theoretical framework, it has to be very careful not to start from pre-suppositions that are problematic. This problem can be easily indicated in respect to the sense-criteria that constitute historical thinking in general. These sense criteria form an essential part of a cultural code which defines the units of comparison. Consequently cultures can be compared along the line of their fundamental concepts which define the forms and realms of reality and human self-understanding. Such a typology of a conceptualisation is a very useful theoretical means for a comparative approach.

\subsection{Dangers of a theory of cultural differences}

Yet, the danger of such a theory of cultural differences lies in its tendency to substantiate or even reify the specific cultures concerned. Their internal historicity, their manifold interferences and mutual conditioning are lost from sight. Comparison is only a statement of dichotomy or of clear alternatives: Historical thinking either follows this code or another one. The related forms of cultural identities look like special realms with clear borderlines. Nothing seems to exist beyond or across the single codes. The typology itself, however, transgresses this borderline in a decisive step and indicates a mode of thinking, which does not necessarily follow one cultural code different from the others. A typology of cultural differences is methodically necessary as a hypothetical construct, but it has to avoid the constraints and misleading views of a concept of cultures as pre-given units and entities.

The idea of cultures as being pre-given is committed to a cultural logic which constitutes identity on the fundamental difference between inside and outside. Such logic conceptualises identity as a mental territory with clear borderlines and a corresponding relationship between self- and otherness as being strictly divided and only externally interrelated. This logic is essentially ethnocentric, and ethnocentrism is inscribed into a typology of cultural differences comparison (concerning the history of human rights) in Rüsen (1994:168-187). 
that treats cultures as coherent units which can clearly be separated from one another.

\subsection{Cultural specifics}

I would like to propose a method of using theoretical conceptualisation which avoids the already mentioned ethnocentrism. Ethnocentrism is theoretically dissolved if the specifics of a culture are understood as a combination of elements which are shared by all other cultures. Thus the specifics of cultures are brought about by different constellations of the same elements. The theoretical approach to cultural differences which is guided by the idea of cultural specifics does not fall into the trap of ethnocentrism. Cultural specifics on the contrary

- presents the otherness of different cultures as a mirror which allows a better self-understanding;

- it does not exclude otherness, when one culture constitutes the peculiarity of itself, but it keeps it included;

- it brings about a balanced interrelationship of cultures: The people who have to deal with their differences from others become empowered with recognition and acknowledgement.

\section{The matrix of historical thinking}

So far my argumentation in which culture is referred to, has been a very general one. It speaks of culture in principle. My subject matter, however, is history. I thus have to specify my idea of culture as an idea of what history is about in all cultures and how this idea can be worked out as a methodical means of intercultural comparison.

\subsection{A logic of historical thinking}

The theoretical approach I would like to propose lies on a level of discourse which can be described as 'metahistorical'. This discourse reflects history and its various modes of dealing with the past; it is not a mode of this dealing but a theory about it. The main issue of this discourse concerns is the sense-criteria which were used to give the past its specific historical meaning and significance for the present. Additionally the constitutive role of needs and interests in dealing with the past and the function of remembering in orienting human activity and of forming all kinds of identity are of constitutive importance in this field. 
The specific logic of historical thinking cannot be explicated without systematically taking into account its constitution and function in practical human life since it is constituted by its relationship to the cultural needs of human activities. It is one of the most important merits of the topical discussion on historical memory to illuminate this point: Historical thinking takes place in the realm of memory and is committed to its mental procedures by which the recalling and representation of the past are dedicated to the cultural orientation of human life in the present. Recalling of the past is a necessary condition of furnishing human life with a cultural frame of orientation that opens up a future perspective, grounded on the experience of the past.

The explication of the logic of historical thinking can be done in the form of a scheme, which explicates five principles of historical thinking and their systematic relationship (Rüsen, 2001:43-105; Rüsen 2004). (See Fig. 1.)

The five principles are:

- interests in cognition generated out of needs for orientation in the temporal change of the present world;

- concepts of significance and perspectives of temporal change, within which the past gets its specific feature as "history";

- rules or methods (in a broad sense of the word) of treating the experience of the past;

- forms of representation, in which the experience of the past, brought about by interpretation into the concepts of significance, is presented in the form of a narrative; and

- functions of cultural orientation in the form of a temporal direction of human activities and concepts of historical identity.

\subsection{The sense-criterion governs the relationship between past and present}

Each of these five factors is necessary and all of them together are sufficient in constituting historical thinking as a rationally elaborated form of historical memory. (It may be useful to underline that not every memory in itself is already a historical one. "Historical" indicates a certain element of temporal distance between past and present, which makes a complex mediation of both necessary.) The five factors may change in the course of time, i.e. in the development of historical thinking in general and historical studies in 
specific. The relationship between these five factors, the systematic order in which they are dependent on one another will, however, remain the same. In this systematic relationship all of them depend upon one main and fundamental principle, which gives their relationship its coherence and the characteristics which historical thinking has in the variety of historical change and development. This main and fundamental principle is the sense-criterion, which governs the relationship between past and present, within which the past gets its significance as "history". 


\subsection{Historical studies and its "scientific" status}

During most of the periods of its development in contemporary times historical studies mainly reflected the cognitive dimension of itself on the level of metahistory. It was eager to legitimate its "scientific" status and its claims for truth and objectivity, thus participating in the cultural prestige of "science" as the most convincing form, in which knowledge and cognition can serve human life. This reflection has been done in a broad variety of different conceptualisations of this "scientific character". In most of these manifestations historical studies claimed for itself a certain epistemological and methodological autonomy in the field of academic disciplines. Doing so, it remained aware of some non-cognitive elements still valid and influential in the work of historical studies - particularly in the field of writing history. Only after the linguistic turn these elements and factors were, however, seen as being as important as the cognitive ones.

The importance of these additional elements and factors can be made plausible in the proposed structure of the five factors of historical thinking in general (and historical studies in particular), if one looks at specific interrelationships: 4

\section{- The relationship between interest and concepts}

In the relationship between interest and concepts historical thinking takes place as a fundamental semantic discourse of symbolising time. Time is related to human activity and suffering in a meaningful and sense-bearing way. In this realm of the human mind fundamental criteria of meaning and sense of history are decided upon.

\section{- The relationship between concepts and methods}

In the relationship between concepts and methods historical thinking is mainly committed to a cognitive strategy of producing historical knowledge. (This strategy constitutes the "scientific" character of historical studies under certain conditions of modernity. It subjugates the discourse of history under the rules of methodical argumentation, conceptual language, control by experience and gaining consent and agreement by rational means.)

4 My sincere thanks to Achim Mittag for a stimulating suggestion to complete my concept of this interrelationship. 


\section{- The relationship between methods and forms}

In the relationship between methods and forms an aesthetic strategy of historical representation takes place. Historical knowledge is shaped. In its form it becomes an element of cultural communication on the temporal dimension of human life. Knowledge of the past adopts the features of present-day life and is furnished with its forces to move the human mind.

This communication is initiated within the interaction between the forms of representation and the functions of cultural orientation. In this respect historical thinking is ruled by a rhetorical strategy of offering cultural orientation.

\section{- The relationship between interests and functions}

Finally, in the relationship between interests and functions historical studies is committed to a political discourse of collective memory. It places the work of historians into the struggle of power and recognition and makes it a necessary means of legitimising or delegitimising all forms of domination and government. Taking all the strategies together, historical thinking can be made visible as a complex synthesis of dealing with the past in five different dimensions: semantics, cognition, aesthetics, rhetoric, and politics. This synthesis stand for an order of history as an integral part of culture. 


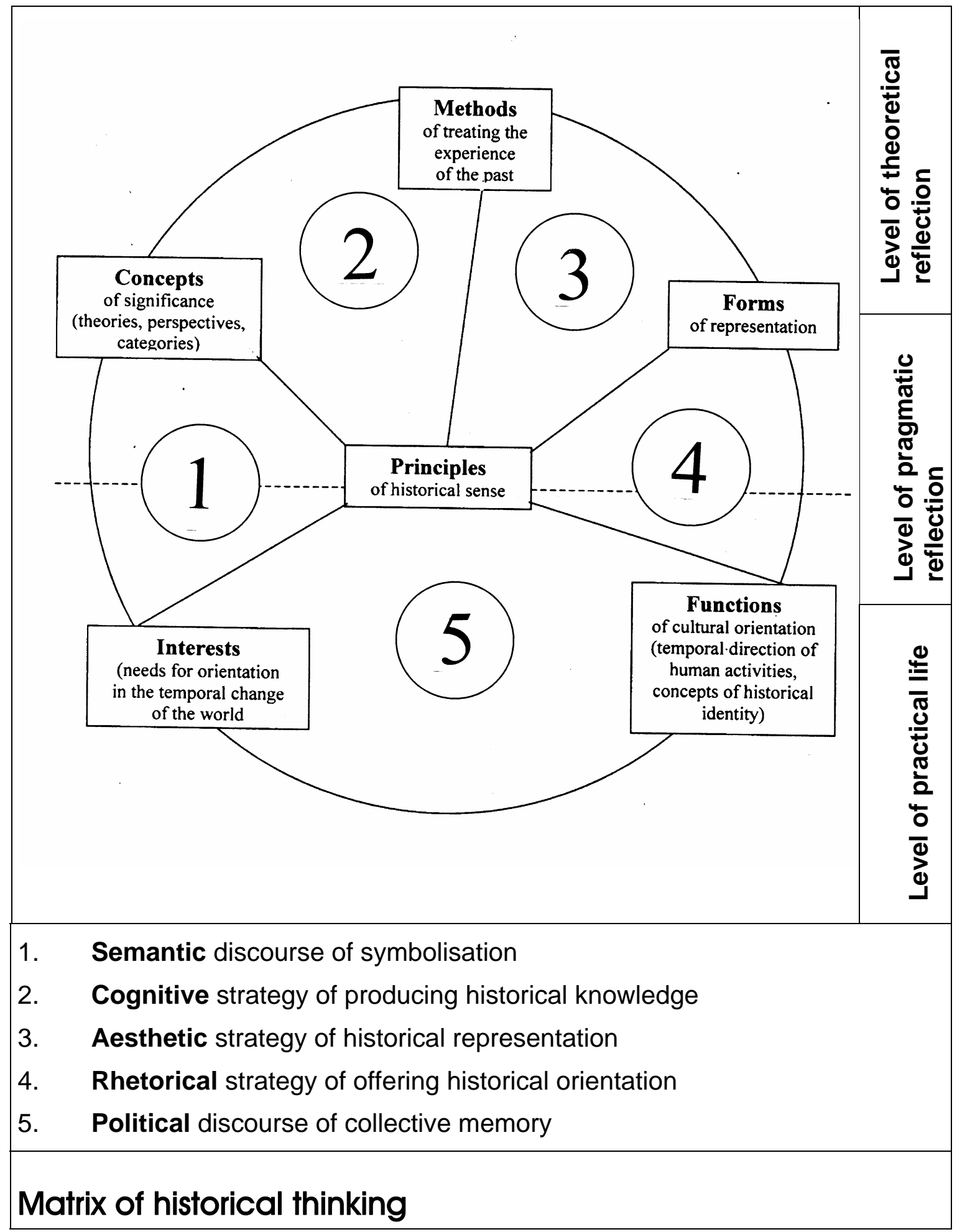

(Fig. 1)

\subsection{Proposed scheme: constitutive factors of historical thinking}

The proposed scheme of the constitutive factors of historical thinking shows the complexity of the work of historians. On the one hand, the 
work of historians is influenced by and related to practical life; on the other hand it has its own realm of gaining knowledge beyond the practical purposes of life orientation. It makes plausible why history has always been rewritten - according to the changes in interests and functions of historical knowledge in human life - and why, at the same time, development, even progress in the cognitive strategy to obtain knowledge about the past is possible.

As every scheme illuminates complex phenomena and at the same time takes parts of it beyond of our awareness, it should be briefly indicated that there are elements in dealing historically with the past that are not addressed by the proposed system of principles. Thus for example, in the realm of constitutive interests there is already an experience of the past. It is substantially different from the experience treated methodically in the realm of elaborated historical thinking. The past is already present when historical thinking starts with questions, initiated by needs for and interests in historical memory. The past plays an important role in shaping these interests and needs. This is the case in very different forms: as an effective tradition, as a fascination of alterity, as a traumatic pressure and even as forgetfulness, that, nevertheless, keeps the past alive by suppressing it.

\section{Criteria for intercultural comparison}

Along this line of argumentation it is now possible to list a series of points of view which can be used for intercultural comparison. The following items only have an illustrative function. It depends upon the materials to be compared which item is useful, which can be omitted, and which has still to be developed. $\mathbf{5}$

\section{- Interests: needs for orientation and perspectives}

Concerning the interests one has to look for needs for orientation and perspectives in which self and society may be seen in an overall meaningful order. Such an interest can inter alia be a "natural" interest in the continuation of cultural orientations; a 'natural' intention of the human heart and soul, a need for the legitimisation of certain forms of life, of certain "belief systems" of political power, of social inequality, an interest in discontinuity, criticism, distinction

5 The following list has been worked out in close cooperation with Horst Walter Blanke and Achim Mittag in their research project on comparing Western and Chinese historical thinking, funded by the Volkswagen-Foundation. 
etc. In order to understand these interests and needs one can ask for challenges that arouse historical consciousness. Normally, the historical mind is basically negatively constituted, i.e. by experiences of ruptures, loss, and disorder; by experiences of structural defects and dissonances, of suffering, disaster, misfortune, domination, suppression, or by experiences of specific or accidental challenges, experiences of arbitrary occurrences and casual events. In this respect the horror of contingency takes place, a horror which has got the specific feature of a historical trauma in contemporary history. Other challenges can be the fascination with the past or experiences of encountering the Other.

\section{- Concepts and patterns of interpretation}

Concerning the concepts and patterns of interpretation, one has to look for sense criteria and leading views of the past by which past human affairs are transformed into history, i.e. the remembered past rendered meaningfully. Of highest importance are basic resources of sense and meaning (so-called "belief systems"). They decide about the ability of integrating "negative sense" and experiences of encountering the Other, the definitive zones of sense and meaning and the limit to which extent senselessness is allowed. They specify what is regarded as historical and what is subjected to historicisation. The whole field of the semantics of historical sense generation has to be taken into account: fundamental notions and concepts. They generate types of historical sense and meaning (like Nietzsche's distinction between a monumental, antiquarian, and critical mode - Nietzsche, [1980]; or Rüsen's typology of traditional, exemplary, critical, and genetic historical sense generation [Rüsen, 1987:87-97; Rüsen, 1993a; Rüsen, 1989:35-60]; or Hayden White's tropes of metaphor - metonymy - synecdoche - irony, constituting the meaning of a historical text [White, 1973]). Of special interest are topoi of historical narration and modes of argumentation like spontaneous and unsystematic, immanent (not reflective), and systematic (e.g. in the form of a philosophy of history). Timeconcepts (Rüsen, 2002:189-205) play a categorical role in interrelating the past, present, and future.

\section{- Procedures of interpretation,}

Concerning the procedures of interpretation, one has to look for mental operations, criteria of plausibility, rules of empirical research, modes of discourse (like monological or dialogical), types of rationality and argumentation, especially in the form of methods. 


\section{- Forms of representation}

Concerning the forms of representation one has to look for the aesthetic dimension of historical narrations, the media, forms of language and expression, differentiations of narrativity (e.g. narrative and non-narrative elements in historical representations).

\section{- Functions}

Concerning the functions, one has to look for the role historical representations play in the cultural orientation of human life. How does it enable people to come to terms with permanence and change? How does it refer to the legitimacy of political power? How does it address the intention of human action? Historical thinking is a necessary means to build, formulate and express one's identity. Special attention thus needs to be given to this basic element of human culture, to the self-awareness of one's own identity by encountering the other, to the range of collective identity as defining historical space, and to the relationship between universal and regional perspectives.

There are still some items of comparison, beyond the field which is disclosed by the matrix of historical thinking, outlined above. They are related to the context within which historical thinking takes place. Finally some factors of this context are thus listed which influence or even determine the way history is brought about within the framework of its specific logic (as it is explicated by the matrix): types of conduct that presuppose some kind of historical sensemaking, especially to those that are related to the cultural memory, cultural practices of narrating, and the whole social network within which the historical discourse takes place.

All the above-mentioned items simply are a collection within, and outside, the abstract systematic order of the matrix. They indicate what should be asked for and taken into account in intercultural comparison.

\section{Towards diachronic comparison}

An unsolved problem still exists: Historical thinking changes in the course of time; it has its own historicity. Can we develop a theoretical framework for comparing this change as well? Up to now most of the listed items of comparison can only serve for a synchronic approach. What about a diachronic approach? 
Diachronic comparison is related to change in historiography. Theoretically undertaken, it has to identify comprehensive factors, modes of processes, and directions of change. Before explicating corresponding perspectives of change in historiography, a general periodisation should, however, be reflected within which historiography gets its historical significance related to the entire process of change in the human world. Such a periodisation realises the dependence of historiography on its context, by which it receives its constitutive challenges, its basic sense-criteria. In this respect it fulfils (or lacks) its orientational function. It is an intensively debated question whether the main epochs of European history could be applied to other cultures. If not, the different periodisations should, at least, be compared in respect to the criteria which determine the division of epochs.

For the purposes of historiography a general periodisation which relates to the dominant media of human communication is useful. Nobody will deny that a distinction between the three epochs, which are defined by the three media orality, scribality, and "electronality" 6 may serve as a first approach to indicate a comprehensive perspective of cultural change.

Coming closer to the specific development of historiography, one has to look at those factors and elements that cause change in the procedure of making sense and representing the past. To give one example for such a moving force of changing historiography, I would like to hint at the increase of knowledge of the past. Such knowledge can challenge new categorisations, and these new categorisations reshape and restructure historiography in general. Without the exploding increase of knowledge the rise of historicist thought in the late 18th century could not be sufficiently explained. There was a similar accumulation of historical knowledge in China, but it does not seem to have brought about a shift in the underlying categories of historical perception and interpretation.

Another question is related to the presentation of change in historiography. Is there anything like the experience of progress, based upon self-esteem of a successful group the historiographers can associate with? 


\subsection{The direction of change}

The most important parameter of diachronic comparison is the direction of change. Is it possible to develop tendencies of change which comprehend different cultures? Today even this question is highly disregarded. It seems too much loaded with the ideological burden of Western supremacy. But a rejection of Western ideology should not lead to a prohibition of asking questions. I think that such a question is unavoidable, since all countries of the world today are directly or indirectly involved in the process of modernisation, and this modernisation is a challenge of historical identity for all of them. It is of high importance to know whether there are tendencies in one's own cultural history which point into the same direction as the Western development. And for Westerners it is useful to know whether there are tendencies in non-Western cultures which have a similar direction of development as their own. If a cultural development exists, or evolution, potentially involving all countries, then the modernisation process will be more than a mere threat of alienation. It may even be conceptualised as an opportunity of gaining or regaining one's own identity in a broader perspective of humankind.

\subsection{No historiography without rationality}

Max Weber's concept of universal rationalisation and disenchantment should thus be reformulated as a question for a comparative analysis of historiography. There is no historiography without rationality, i.e. a set of rules, which bind the sense-making process of historical consciousness into strategies of conceptualisation, of bringing empirical evidence into the representation of the past, and of coherent argumentation. This rationality should be reconstructed and investigated in respect to its development towards a growing universality of its validity. The same should be done in respect to the norms and values which constitute historical identity. Do they show a directed development which can be described as a process of universalisation, and does the spatial extension of historical identity develop accordingly? I think we can observe such a process of universalisation in many cultures: ${ }^{7}$ It started from a small social group in archaic times and has lead to mankind in contemporary history. Concomitantly with this universalisation very often a corresponding regionalisation takes place.

7 I tried to conceptualise such a process in respect of the issue of their universality of human rights and the general issues of humankind, selfness, and otherness (Schmale, 1993:28-46; see Rüsen, 1993:167-178). 
Additionally one should look for a process of particularisation and individualisation; it may be a reaction to universalisation or a consequence of it.

\subsection{The treatment of "facts" in relationship to the pre- supposed order of time}

Another direction of development can be conceptualised in respect to the treatment of "facts" in relationship to the presupposed order of time. Is there a comprehensive process of "positivation" of historiography by increasingly integrating positive facts and principles of temporal order? In archaic societies the "facts", occurring in human life are not important for the narrative presentation of the divine order of the world in space and time. Myths as narratives, which present world order, are not very much related to chronologically fixed dates given and proved by empirical evidence. As a result of a long development the mythical order has vanished or has been mixed up with the temporal chain of positive, i.e. "factual" events and structures.

Following this line of argument, I want to outline a periodisation which is basically related to the media of cultural communication and its transformation. This kind of periodisation may function as a heuristic and hypothetical means of giving historical thinking a comprehensive temporal order. It even indicates a possible development (post-historic period), that presents an ideal-type, composed of the most challenging elements of postmodern historical thinking. 


\section{Universal periodisation of historical thinking ${ }^{8}$}

\begin{tabular}{|c|c|c|c|}
\hline 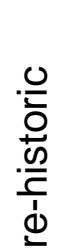 & \multicolumn{3}{|c|}{$\begin{array}{l}\text { Sharp distinction between paradigmatic time of world order } \\
\text { ("archaic" time of myth) and the time of every-day human life; the } \\
\text { latter is meaningless for the order of the world and the self. } \\
\text { Contingency is radically sorted out. Dominance of the traditional } \\
\text { type of historical narration. Medium of oral tradition }\end{array}$} \\
\hline \multirow[b]{2}{*}{$\frac{0}{\frac{0}{0}}$} & \multirow{2}{*}{$\begin{array}{l}\text { Intermediation } \\
\text { of both } \\
\text { "times". Con- } \\
\text { tingent facts } \\
\text { (events) are } \\
\text { loaded with } \\
\text { meaning con- } \\
\text { cerning the } \\
\text { temporal world } \\
\text { order. } \\
\text { Contingency is } \\
\text { recognised as } \\
\text { relevant for } \\
\text { this order and } \\
\text { bound into a } \\
\text { concept of } \\
\text { time that } \\
\text { orientates } \\
\text { practical } \\
\text { activity and } \\
\text { forms human } \\
\text { identity. } \\
\text { Medium of } \\
\text { scripture. }\end{array}$} & 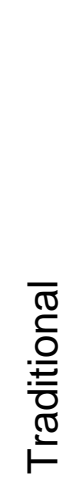 & $\begin{array}{l}\text { The entire order of time has a divine } \\
\text { character. Religion is the main source for } \\
\text { sense of temporal change. Dominance of } \\
\text { the exemplary type of historical narration. }\end{array}$ \\
\hline & & $\begin{array}{l}\frac{5}{\frac{5}{O}} \\
\frac{0}{2}\end{array}$ & $\begin{array}{l}\text { Minimalisation of transcendental } \\
\text { dimension of time-order. The entire sense } \\
\text { of history tends to become innerworldly. } \\
\text { Human rationality is able to recognise it } \\
\text { by means of methodical research of the } \\
\text { empirical evidence of the past. } \\
\text { Dominance of the genetic type of } \\
\text { historical narration }\end{array}$ \\
\hline 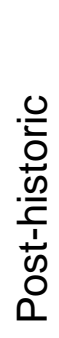 & \multicolumn{3}{|c|}{$\begin{array}{l}\text { No comprehensive order of time including past, present, and } \\
\text { future. The past is separated into a time of itself. Facts of the past } \\
\text { become elements of arbitrary constellations that have no } \\
\text { substantial relationship to present and future. The human past } \\
\text { becomes de-temporalised. Contingency loses its concept- } \\
\text { ualisation by ideas of temporal order valid for present-day life and } \\
\text { its future. Medium of electronics. }\end{array}$} \\
\hline
\end{tabular}

8 I arranged three of the four types of historical sense-making into a clear order of different periods. This categorisation is misleading, since the four types play a much more complex role in all periods. They nevertheless can be used to characterise an epoch-related kind of historical thinking. The different types are described in Rüsen (2004, footnote 15). 
Modernisation is, of course, one of the most important perspectives of diachronic comparison. It should be concretised as an internal process of rationalisation in dealing with the past. Historical studies as an academic discipline indicate forms and stages of this rationalisation. Rationalisation, however, is only one side of the coin of modernisation. There is always a reaction against it, a reenchantment in the relationship to the past which, at least, compensates for the loss of sense and meaning brought about by the rationality of methodical strategies of research. The comparative approach to historiography thus should always be a double one: the view at disenchantment, as well as at its compensation by an irrational re-enchantment or at its complementation by new or reformulated ("reformatted") sources and potentials of sense, meaning, and significance of the temporal dimension of human life.

Another strong indicator of modernity is the emergence of the concept of "the history" as an entire field of human experience, as a temporal totality of development comprising all cultures of the past, present and future.

\section{Conclusion}

The twentieth century has brought about fundamental challenges of historiography in respect to its basic criteria of sense and meaning. In this respect I think of the traumatic experience of the Holocaust and similar occurrences of mass-murder and other radical irritations of sense in the course of time in the human world. (A Chinese example is at hand, too: The Taiping Rebellion e.g. had 20 million victims.) Such experiences cause traumatic reactions and very often suppress important elements of collective memory into the unconscious. Looking at historiography this unconscious has to be disclosed as a silence of the past, which, nevertheless, influences the present. In order to make this influence plausible, one has to identify indications of this suppression in the articulated representations of the past. In order to meet these challenges our interpretation of historiography has to systematically take into account intended or unintended procedures of a negative mode of making sense of history. This negative sense or the sense of senselessness can be demonstrated as "limits of representation" that have already been paradigmatically discussed in respect to the Holocaust (Friedlander, 1992). It seems to be a fruitful quest to look for such limits even in ordinary historiography, thus bringing to our awareness a 
dimension of historical consciousness in which historiography speaks the language of silence. ${ }^{9}$

In the introductory remarks of this article I pointed out the fact that every work in historiography, including comparison, is involved in the process of identity formation and is guided by practical interests. This is true for the proposed strategy of pursuing comparative interpretation of historiography as well. The practical objective of this strategy is a negative and a positive one.

- Negatively, this practical objective should prevent ideological generalisations of cultural peculiarity becoming presuppositions and guidelines for the study of historiography, thus avoiding the widespread dichotomy between self and other and the related strategy of exclusion in identity-formation.

- Positively, this objective should enable scholars to present the historiographical traditions of different cultures, peoples and societies in a mental movement between sameness and difference, by which those whose identity is at stake, are put into the position of becoming aware that otherness is a mirror for their self-awareness. Then their communication can become an effort of mutual recognition and acknowledgement (Rüsen, 2002).

\section{List of references}

ASTHANA, P. 1992. The Indian view of history. Agra: MG Publishers.

BEASLEY, W.G. \& PULLEYBLANK, E.G., eds. 1962. Historians of China and Japan. Second ed. London: Oxford University Press.

BLANKE, H.W. 1991. Historiographiegeschichte als Historik. Fundamenta Historica III. Stuttgart-Bad Cannstatt: Fromann-Holzboog.

BREISACH, E. 1983. Historiography - ancient, medieval, and modern. Chicago: University of Chicago Press.

BROWN, D.E. 1988. Hierarchy, history and human nature: the social origins of historical consciousness. Tuscon: University of Arizona Press.

DEVAHUTI, D., ed. 1979. Problems of Indian historiography. Delhi: DK Publications.

FRIEDLÄNDER, S., ed. 1992. Probing the limits of representation: Nazism and the "Final Solution". Cambridge: Harvard University Press.

GARDNER, C.S. 1961. Chinese traditional historiography. Cambridge: Harvard University Press.

9 Concerning the fall of Nanking (1867) an already established literary pattern of suppressive memory was applied, that articulated a weariness of looking back: "And I fear to look back, to read too carefully Yü Hsin's fu" (Owen, 1990:417457). 
GOTTLOB, M. 1995. Writing the history of modern Indian historiography. Storia del la Storiografia, 27:123-144.

HAUPT, H.-G. \& KOCKA, J., eds. 1996. Geschichte und Vergleich: Ansätze und Ergebnisse international vergleichender Geschichtsschreibung. Frankfurt am Main: Campus Verlag.

IGGERS, G.G. 1993. Geschichtswissenschaft im 20. Jahrhundert: ein Überblick im internationalen Zusammenhang. Göttingen: Vandenhoeck \& Ruprecht.

IGGERS, G.G. \& Parker, H.T., eds. 1979. International handbook of historical studies: contemporary research and theory. Westport: Greenwood.

KAO, G., ed. 1982. The translation of things past: Chinese history and historiography. Hong Kong: Chinese University Press.

KÜTTLER, W., RÜSEN, J. \& SCHULIN, E. 1993. Geschichtsdiskurs I: Grundlagen und Methoden der Historiographiegeschichte. Frankfurt am Main: Fischer Wissenschaft.

KÜTTLER, W., RÜSEN, J. \& SCHULIN, E., Reds. 1994. Geschichtsdiskurs II: Anfänge modernen historischen Denkens. Frankfurt am Main: Fischer Wissenschaft.

KÜTTLER, W., RÜSEN, J. \& SCHULIN, E., Reds. 1996. Geschichtsdiskurs III: die Epoche der Historisierung. Frankfurt am Main: Fischer Wissenschaft.

KÜTTLER, W., RÜSEN, J. \& SCHULIN, E., Reds. 1997. Geschichtsdiskurs IV: Krisenbewußtsein, Katastrophenerfahrungen und Innovationen 18801945. Frankfurt am Main: Fischer Wissenschaft.

KÜTTLER, W., RÜSEN, J. \& SCHULIN, E., Reds. 1999. Geschichtsdiskurs V: Globale Konflikte, Erinnerungsarbeit und Neuorientierungen seit 1945. Frankfurt am Main: Fischer Wissenschaf.

NIETZSCHE, F. 1980. On the advantage and disadvantage of history for life. Translated by P. Preuss. Indianapolis: Hackett.

OSTERHAMMEL, J. 1996. Sozialgeschichte im Zivilisationsvergleich: zu künftigen Möglichkeiten komparativer Geschichtswissenschaft. Geschichte und Gesellschaft, 22:143-164.

OWEN, S. 1990. Place: mediation on the past at Chin-ling. Harvard Journal of Asiatic Studies, 56:417-457.

ROSENTHAL, F. 1968. History of Muslim historiography. 2nd revised edition. Leiden: Brill.

RÜSEN, J. 1987. Historical narration: foundation, types, reason. History and Theory, Beiheft 26: The Representation of Historical Events, p. 87-97.

RÜSEN, J. 1989. The development of narrative competence in historical learning - an ontogenetical hypothesis concerning moral consciousness. History and Memory, 1(2):35-60.

RÜSEN, J. 1993. Human rights from the perspective of a universal history. (In Schmale, W., ed., Human rights and cultural diversity: Europe - Arabic/ Islamic World - Africa - China. Goldbach: Keip. p. 28-46.)

RÜSEN, J. 1993a. Studies in metahistory. Pretoria: Human Science Research Council.

RÜSEN, J. 1993b. Vom Umgang mit den Anderen - Zum Stand der Menschenrechte heute. Internationale Schulbuchforschung, 15:167-178.

RÜSEN, J. 1994. Historische Orientierung: über die Arbeit des Geschichtsbewußtseins, sich in der Zeit zurechtzufinden. Köln: Böhlau.

RÜSEN, J. 2001. Zerbrechende Zeit: über den Sinn der Geschichte. Köln: Böhlau. 
RÜSEN, J. 2002. Making sense of time - towards an universal typology of conceptual foundations of historical consciousness. Taida lishi xuebao, 29:189-205. (In Chinese: Wei shi Li Yi: mai xiang lishi yishi jichu guannian zhi pubianxing leixingxue), Dangdai, 155 (2000). p. 36-43, in another translation in Historiographical Quarterly, [Shixue lilun yanjiu]. Peking, 2002.

RÜSEN, J., ed. 2002. Western historical thinking: an intercultural debate. New York: Berghahn Books.

RÜSEN, J. 2004. History: narration - interpretation - orientation. New York: Berghahn Books.

TRAUZETTEL, R. 1984. Die chinesische Geschichtsschreibung. (In Debon, G., Red. Ostasiatische Literaturen. Wiesbaden: Harrassowitz. p. 77-90. Extrême-Orient/Extrême-Occident, IX: La référence à I'histoire. Paris 1986.)

WHITE, H. 1973. Metahistory: the historical imagination in 19th-century Europe. Baltimore: The Johns Hopkins University Press.

\section{Key concepts:}

comparative historiography

criteria of comparison

historical thinking

intercultural comparison

\section{Kernbegrippe:}

historiese nadenke interkulturele vergelyking vergelykende historiografie vergelykingskriteria 
